\title{
Inhibition of Basal and Mitogen-stimulated Pancreatic Cancer Cell Growth by Cyclin D1 Antisense Is Associated with Loss of Tumorigenicity and Potentiation of Cytotoxicity to Cisplatinum
}

\author{
Marko Kornmann, ${ }^{*}$ Nadir Arber, ${ }^{\ddagger}$ and Murray Korc* \\ *Department of Medicine, Department of Biological Chemistry, and Department of Pharmacology, University of California, Irvine, \\ California 92697; and ${ }^{\ddagger}$ Department of Gastroenterology, Tel-Aviv Sourasky Medical Center, Tel-Aviv, Israel
}

\begin{abstract}
Cyclin D1 belongs to a family of protein kinases that have been implicated in cell cycle regulation. Recent studies have demonstrated that elevated cyclin D1 levels correlate with decreased survival in human pancreatic cancer. In this study we expressed in a stable manner a cyclin D1 antisense cDNA construct in PANC-1 human pancreatic cancer cells. Expression of the antisense construct caused a decrease in cyclin D1 mRNA and protein levels and in cyclin D1-associated kinase activity. Antisense expressing clones displayed significantly increased doubling times, decreased anchorage-dependent and -independent basal growth, and complete loss of tumorigenicity in nude mice. EGF, FGF-2, and IGF-I enhanced mitogen-activated protein kinase activity in antisense expressing clones, but failed to stimulate their proliferation. In contrast, all three growth factors were mitogenic in parental cells. Furthermore, the inhibitory effect of cisplatinum on cell proliferation was enhanced markedly in the antisense expressing clones. These findings indicate that cyclin D1 overexpression contributes to abnormal growth and tumorigenicity in human pancreatic cancer and to the resistance of pancreatic cancer to chemotherapeutic agents. (J. Clin. Invest. 1998. 101:344-352.) Key words: cell cycle $\bullet$ chemosensitivity $\bullet$ growth factor $\bullet$ nude mice $\bullet$ kinase activity
\end{abstract}

\section{Introduction}

Cyclins are the regulatory subunits of a protein kinase family. They associate with catalytic cyclin-dependent kinase $(\mathrm{CDK})^{1}$ subunits regulating cell cycle progression (1). To date, $11 \mathrm{cy}-$ clins and 7 CDKs have been identified, termed cyclins A, B1-2,

Address correspondence to Murray Korc, Division of Endocrinology, Diabetes and Metabolism, Med. Sci. I, C240, University of California Irvine, Irvine, CA 92697. Phone: 714-824-2273; FAX: 714-824-1035; E-mail: mkorc@uci.edu

Received for publication 28 July 1997 and accepted in revised form 10 November 1997.

1. Abbreviations used in this paper: $\mathrm{CDK}$, cyclin-dependent kinase; MAPK, mitogen-activated protein kinase; MTT, 3-(4,5-methylthiazol-2-yl)-2,5-diaphenyltertrazolium bromide.

J. Clin. Invest.

(C) The American Society for Clinical Investigation, Inc. 0021-9738/98/01/0344/09 \$2.00

Volume 101, Number 2, January 1998, 344-352

http://www.jci.org
C, D1-3, E, F, G, and H, and CDK1-7 (2). Cyclin D1 is involved in the regulation of the $\mathrm{G}_{1}$ phase of the cell cycle $(3,4)$, an essential period in which cell differentiation is initiated and proliferation is controlled (5). A proposed downstream target of the cyclin D1/CDK complexes is the retinoblastoma tumor suppressor gene product pRb (6-8). Cyclin D1/CDK complexes regulate transcription via the inactivating phosphorylation of $\mathrm{pRb}$ that results in the liberation of several nuclear proteins $(3,4)$. One of these proteins is E2F, which initiates the transcription of genes required for $\mathrm{S}$ phase progression $(9,10)$. In contrast to events that occur after cells enter into the $S$ phase, cell cycle events in the $G_{1}$ phase can be influenced by extracellular growth factors (5). Mitogenic growth factors initiate cascades of events during the $\mathrm{G}_{1}$ phase via specific signaling pathways promoting cell cycle progression by enhancing the assembly of cyclin/CDK complex formation and kinase activities (2-4). Elevated cyclin D1 mRNA levels reduce the dependency of cells on exogenous mitogens, shorten the $G_{1}$ phase, and decrease cell size (11-13). Therefore, the overexpression of growth factors in conjunction with deregulated cyclin D1 expression has been proposed to contribute to the loss of cell cycle control and to enhance tumorigenesis (14).

Human pancreatic cancer, an aggressive and devastating disease with poor prognosis (15), is frequently associated with overexpression of growth factors and their receptors (16-19) and with resistance to chemotherapeutic agents (20). Cyclin D1 is overexpressed in a significant proportion of human pancreatic cancers and elevated cyclin D1 levels correlate with decreased postoperative patient survival $(21,22)$. However, the functional significance of cyclin D1 overexpression in this disorder is not known. In this study, therefore, we overexpressed a cyclin D1 antisense cDNA construct in PANC-1 cells, a human pancreatic cancer cell line that expresses cyclin D1 at relatively high levels. We now report that cyclin D1 antisense expression reduces cyclin D1 protein levels and cyclin D1associated kinase activity and that these events are associated with significant inhibition of in vitro and in vivo cell proliferation, decreased mitogenic response, and increased chemosensitivity.

\section{Methods}

Materials. Random-primed labeling kits were purchased from Ambion (Austin, TX), $\left[\gamma_{-}{ }^{32} \mathrm{P}\right] \mathrm{ATP},\left[\alpha^{-}{ }^{32} \mathrm{P}\right] \mathrm{CTP},\left[\alpha{ }^{-32} \mathrm{P}\right] \mathrm{dCTP}$, and horseradish-conjugated antibodies from Amersham (Arlington Heights, IL), PANC-1 human pancreatic cancer cells and pRSVneo plasmid from American Type Culture Collection (Rockville, MD), T7 and SP6 RNA polymerase from Boehringer Mannheim (Mannheim, Germany), Noble agar from Difco Laboratories (Detroit, MI), G418 from Gibco Laboratories (Grand Island, NY), lipofectamine reagent from Life Technologies (Gaithersburg, MD), Immobilon-P nitrocellulose membranes from Millipore Corp. (Bedford, MA), mouse monoclonal anti-cyclin D1 antibodies (clones DCS-6 and DCS-11) from 
Neomarkers Inc. (Fremont, CA), enhanced chemiluminescence substrate from Pierce (Rockford, IL), anti-active mitogen-activated protein kinase (MAPK) rabbit polyclonal antibody from Promega (Madison, WI), anti-ERK-2 antibody and glutathione $S$-transferase$\mathrm{pRb}$ fusion protein from Santa Cruz Biotechnology (Santa Cruz, CA), cis-platinum (II)-diammine dichloride, 3-(4,5-methylthiazol-2-yl)2,5-diaphenyltertrazolium bromide (MTT), and protein A-Sepharose from Sigma Chemical Co. (St. Louis, MO), and human IGF-I from United States Biochemical Corp. (Cleveland, OH). COLO-357 human pancreatic cancer cells were a gift from R.S. Metzgar (Duke University, Durham, NC), human EGF from G. Nascimoto (Chiron Co., Emmeryville, CA), and human FGF-2 from J. Abrahams (Scios Nova Co., Mountain View, CA).

Cell culture. PANC-1 and COLO-357 cells were grown in DME, supplemented with $8 \%$ FBS, penicillin $\mathrm{G}(100 \mathrm{U} / \mathrm{ml})$, and streptomycin $(100 \mu \mathrm{g} / \mathrm{ml})$, termed complete medium, and maintained in monolayer culture at $37^{\circ} \mathrm{C}$ in humidified air with $5 \% \mathrm{CO}_{2}$. The medium for cell lines containing a neomycin resistance gene was supplemented with 1 and $0.5 \mathrm{mg} / \mathrm{ml} \mathrm{G} 418$ for PANC-1 and COLO-357 cells, respectively. Viability of the cells was determined by trypan blue staining.

Constructs. The 1.1-kb human cyclin D1 cDNA that contains the entire coding sequence was subcloned in its antisense orientation into the retroviral expression vector pMV7, termed pMV7D1AS (23). The pMV7 vector contained a 5' moloney murine leukemia virus (MoMuLV) LTR, followed by the 1.1-kb antisense cyclin D1 sequence, a herpes simplex thymidine kinase promoter linked to the G418 resistance gene, and a 3' MoMuLV LTR. The pRSVneo plasmid containing the G418 resistance gene was used to establish control clones expressing vehicle vector alone, termed sham.

Transfection. PANC-1 and COLO-357 cells were transfected in a stable manner with the pMV7D1AS plasmid and the pRSVneo vector control plasmid with lipofectamine reagent using the conditions described by the supplier (Life Technologies). In brief, $4 \times 10^{5}$ cells were seeded per 10-cm dish and grown in complete medium for $24 \mathrm{~h}$. Plasmid DNA $(15 \mu \mathrm{g})$ and lipofectamine $(40 \mu \mathrm{l})$ were mixed in $6 \mathrm{ml}$ of serum-free medium and incubated for $30 \mathrm{~min}$ at $23^{\circ} \mathrm{C}$. Cells were then incubated for $5 \mathrm{~h}$ at $37^{\circ} \mathrm{C}$ with the DNA lipofectamine mixture and for an additional $19 \mathrm{~h}$ after adding $6 \mathrm{ml}$ of DME containing $20 \%$ FBS. Selection of individual independent clones was performed as described previously (24). Briefly, cells were plated at a 1:10 dilution in selection medium containing 1 and $0.5 \mathrm{mg} / \mathrm{ml} \mathrm{G} 418$ for PANC-1 and COLO-357 cells, respectively. After 2-3 wk, single, independent clones of cells were randomly isolated, and each individual clone was plated separately. After clonal expansion, cells from each independent clone were tested for cyclin D1 levels and cyclin D1 antisense expression as described in the following paragraphs.

Immunoblotting. Exponentially growing cells $(\sim 40-50 \%$ confluent) were washed twice with ice-cold PBS and lysed in buffer containing $125 \mathrm{mM}$ Tris ( $\mathrm{pH}$ 6.8) and 1\% SDS. Cell lysates were subjected to SDS-PAGE and electrotransferred to Immobilon-P membranes. After blocking, the membranes were blotted with a highly specific anticyclin D1 antibody (DCS-6) and with a secondary horseradish-conjugated antibody $(22,25,26)$. Bound antibodies were visualized using enhanced chemiluminescence. To confirm equal loading, membranes were stripped for $30 \mathrm{~min}$ at $50^{\circ} \mathrm{C}$ in buffer containing $2 \%$ SDS, $62.5 \mathrm{mM}$ Tris (pH 6.7), and $100 \mathrm{mM}$ 2-mercaptoethanol and blotted with an anti-ERK-2 antibody.

Cyclin D1 kinase activity assay. The cyclin D1 kinase activity assay was performed as described previously $(23,25,26)$. Exponentially growing cells were washed twice with ice-cold PBS and lysed in buffer containing $10 \%$ glycerol, $50 \mathrm{mM}$ Hepes ( $\mathrm{pH} 7.5$ ), $150 \mathrm{mM}$ sodium chloride, $1 \mathrm{mM}$ EDTA, $2.5 \mathrm{mM}$ EGTA, $1 \mathrm{mM}$ DTT, $0.1 \%$ Tween 20 , $10 \mathrm{mM} \beta$-glycerophosphate, $1 \mathrm{mM}$ sodium fluoride, $0.1 \mathrm{mM}$ sodium orthovanadate, $50 \mu \mathrm{g} / \mathrm{ml}$ aprotinin, $10 \mu \mathrm{g} / \mathrm{ml}$ leupeptin, $10 \mu \mathrm{g} / \mathrm{ml}$ pepstatin A, $10 \mu \mathrm{g} / \mathrm{ml}$ benzamidine, and $1 \mathrm{mM}$ PMSF. After sonicating and clarifying by centrifugation, the cell lysate solutions were incubated for $2 \mathrm{~h}$ with $2 \mu \mathrm{g}$ of a highly specific anti-cyclin D1 antibody (DCS-11) at $23^{\circ} \mathrm{C}$ and for $1 \mathrm{~h}$ after adding $25 \mu \mathrm{l}$ of slurry protein
A-Sepharose (27). Immunocomplexes were captured by centrifugation and washed four times with lysis buffer and twice with $50 \mathrm{mM}$ Hepes ( $\mathrm{pH}$ 7.5) containing $1 \mathrm{mM}$ DTT. The beads were suspended in $30 \mu \mathrm{l}$ of kinase buffer containing $50 \mathrm{mM}$ Hepes ( $\mathrm{pH} 7.5), 10 \mathrm{mM}$ magnesium chloride, $1 \mathrm{mM}$ DTT, $2.5 \mathrm{mM}$ EGTA, $10 \mathrm{mM} \beta$-glycerophosphate, $0.1 \mathrm{mM}$ sodium orthovanadate, $1 \mathrm{mM}$ sodium fluoride, $20 \mathrm{mM}$ ATP, and $5 \mu \mathrm{Ci}\left[\gamma^{-32} \mathrm{P}\right] \mathrm{ATP}(3,000 \mathrm{Ci} / \mathrm{mmol})$, and $0.3 \mu \mathrm{g}$ of soluble glutathione $S$-transferase-pRb fusion protein as a substrate. After incubation for $20 \mathrm{~min}$ at $30^{\circ} \mathrm{C}$, samples were suspended in $5 \times$ Laemmli buffer, boiled for $5 \mathrm{~min}$ at $100^{\circ} \mathrm{C}$, and subjected to SDS-PAGE. The dried gels were exposed to Kodak XAR-5 films at $-80^{\circ} \mathrm{C}$ using intensifying screens.

Northern blot analysis. Total RNA $(10 \mu \mathrm{g})$ from exponentially growing cells was prepared by the acid guanidinium thiocyanate method, size-fractionated on $0.8 \%$ agarose $/ 2.2 \%$ formaldehyde gels, electrotransferred, and ultraviolet cross-linked onto nylon membranes. The blots were then prehybridized, hybridized, and washed under high stringency conditions as described, depending on whether sense and antisense cyclin D1 cRNA or 7S cDNA probes were used $(16,23)$. The mouse $7 \mathrm{~S}$ fragment was used to document equivalent RNA loading (16). Blots were exposed to Kodak XAR-5 films at $-80^{\circ} \mathrm{C}$ using intensifying screens. The full-length cyclin D1 antisense cDNA was subcloned into pGEM-7Zf and used to generate antisense riboprobes for cyclin D1 and cyclin D1 antisense cDNAs. cRNA probes were labeled with $\left[\alpha{ }^{3}{ }^{32} \mathrm{P}\right] \mathrm{CTP}(3,000 \mathrm{Ci} / \mathrm{mmol})$ using $\mathrm{T} 7$ and SP6 RNA polymerase, respectively, and cDNA probes were randomprimed labeled with $\left[\alpha-{ }^{32} \mathrm{P}\right] \mathrm{dCTP}$.

Cell growth assays. Anchorage-dependent cell growth was determined by the MTT colorimetric growth assay (28). Briefly, cells were cultured in 96-well plates and incubated for $4 \mathrm{~h}$ with $0.625 \mu \mathrm{g} / \mathrm{ml}$ MTT. After removal of the medium, the dye crystals were dissolved in acidified isopropanol and the optical density was measured at 570 and $650 \mathrm{~nm}$ with an ELISA plate reader as described (29). We have demonstrated previously that cell proliferation of pancreatic and colon carcinoma cell lines determined by this assay closely correlates with cell counting and $\left[\mathrm{H}^{3}\right]$ thymidine incorporation $(19,30,31)$.

To determine basal growth, $1.5 \times 10^{4}$ cells/well were plated and incubated for $48 \mathrm{~h}$ in $200 \mu \mathrm{l}$ of complete medium. To determine doubling times, $3.0 \times 10^{3}$ cells/well were plated and incubated in complete medium. The optical densities on one plate were determined daily. Doubling times were also assessed by cell counting with a hemacytometer, after plating $5 \times 10^{4}$ cells/well in 6-well plates.

To assess the mitogenic effects of EGF, FGF-2, and IGF-I, $1.5 \times$ $10^{4}$ cells/well were plated and incubated for $24 \mathrm{~h}$ in complete medium and for $48 \mathrm{~h}$ in serum-free medium containing antibiotics, $0.1 \%$ BSA, $5 \mathrm{mg} /$ liter transferrin, and $5 \mu \mathrm{g} / \mathrm{liter}$ selenious acid in the absence or presence of the ligands. Medium was replaced with fresh serum-free medium containing the respective additions after $24 \mathrm{~h}$.

To assess the chemosensitivity to cisplatinum, $1.5 \times 10^{4}$ cells $/$ well were plated and incubated for $48 \mathrm{~h}$ in complete medium. After $24 \mathrm{~h}$, cisplatinum was added as indicated for $6 \mathrm{~h}$ or $60 \mathrm{~min}$. These assay settings were chosen because they include cisplatinum exposure times that are recommended for regional chemotherapy via the celiac arterial axis in vivo (32). The effects of cisplatinum $(10 \mu \mathrm{g} / \mathrm{ml})$ on cell number and viability were also determined by cell counting and trypan blue staining with a hemacytometer, after seeding $10^{5}$ cells/well in 12-well plates.

Basal anchorage-independent growth was assessed by a doublelayer soft agar assay (33). Briefly, $4 \times 10^{3}$ viable cells were suspended in complete medium containing $0.3 \%$ agar and seeded in triplicate in 6-well plates onto a base layer of complete medium containing $0.5 \%$ agar. $1 \mathrm{ml}$ of complete medium containing $0.3 \%$ agar was added every $5 \mathrm{~d}$. After $14 \mathrm{~d}$, colonies $>100 \mu \mathrm{m}$ in diameter were counted by microscopy (Inverted Diaphot 300; Nikon Inc., Melville, NY) and stained with MTT solution (300 $\mu \mathrm{g} /$ well) for $24 \mathrm{~h}$.

In vivo tumorigenicity assay. To assess the effect of antisense cyclin D1 on tumorigenicity, $3 \times 10^{6}$ cells expressing vector alone or cyclin D1 antisense were injected subcutaneously into multiple sites of 
4-6-wk old, female, athymic (nude) mice. The animals were monitored for tumor formation every week and killed 8-12 wk after injection.

MAPK assay. Cells were cultured in 6-well plates for $24 \mathrm{~h}$ in complete medium to $50 \%$ confluency and then for $18 \mathrm{~h}$ in serum-free medium before stimulation with ligands. The cells were lysed in a modified RIPA buffer as described previously (29). Cell extracts (25 $\mu \mathrm{g} / \mathrm{lane}$ ) were subjected to $12 \%$ SDS-PAGE. Western blot analysis was carried out with anti-active MAPK antibodies and secondary horseradish-conjugated antibodies according to the protocol of the manufacturer (Promega).

Statistics. Statistical analysis was performed with SigmaStat software (Jandel Scientific, San Raphael, CA). Results are expressed as mean \pm SD or as mean \pm SEM and the Student's $t$ test and the Fisher exact test were used for statistical analysis (two-sided). $P<0.05$ was taken as level of significance.

\section{Results}

Expression of antisense cyclin D1 in PANC-1 human pancreatic cancer cells. To investigate the functional significance of cyclin D1 expression in pancreatic cancer cells, we overexpressed a cyclin D1 antisense cDNA construct in PANC-1 human pancreatic cancer cells. Overall, 48 independent clones were selected after 3 wk of growth in medium supplemented with G418. Four clones were dropped during the subsequent expansion process since they were growing too slowly. After clonal expansion, the remaining 44 clones of cells were subjected to immunoblotting to determine the cyclin D1 protein level in each clone. 12 of the 44 clones displayed a marked and

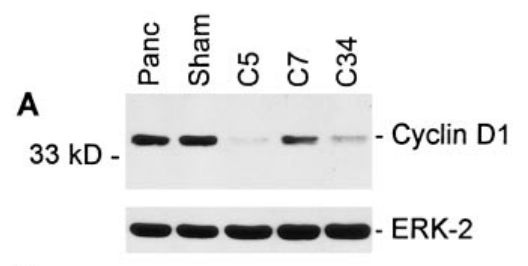

B

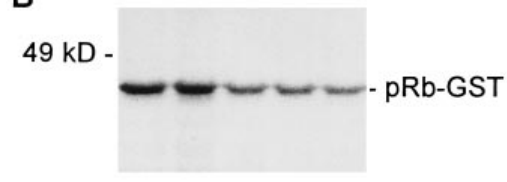

C

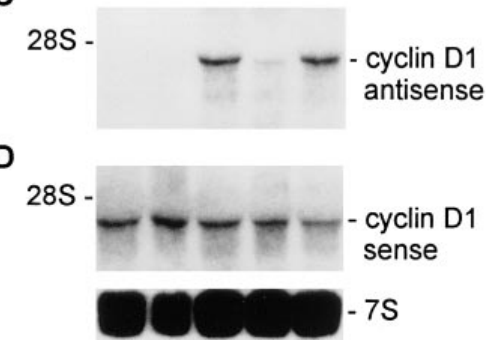

Figure 1. Characterization of cyclin D1 antisense expression in PANC-1 cells. $(A)$ Immunoblotting. Total cell lysates $(25 \mu \mathrm{g} / \mathrm{lane})$ were subjected to $12 \%$ SDS-PAGE, transferred to a membrane, and blotted with anticyclin D1 antibodies (1: 400, 5-min exposure, upper panel) and reprobed with anti-ERK-2 antibodies to confirm equal loading (1:2,000, 1-min exposure, lower panel). (B) Cyclin D1-associated kinase activity. Total cell lysates $(350 \mu \mathrm{g})$ were incubated with anti-cyclin D1 antibodies. Immunocomplexes were captured with protein A-Sepharose, resuspended in kinase buffer containing glutathione $S$-transferase-pRb (pRb-GST) fusion protein as substrate, and subjected to $12 \%$ SDSPAGE after incubation for $20 \mathrm{~min}$ at $30^{\circ} \mathrm{C}$ (2-h exposure). ( $C$ and $D$ ) Northern blotting. Total RNA $(10 \mu \mathrm{g} / \mathrm{lane})$ was size-fractionated, electrotransferred to a membrane, and hybridized with cyclin D1 riboprobes $(250,000 \mathrm{cpm} / \mathrm{ml})$ that can distinguish between cyclin D1 antisense $(C)$ and sense (D, upper panel) transcripts (7-d exposures). A $7 \mathrm{~S}$ cDNA probe $(40,000 \mathrm{cpm} / \mathrm{ml} ; 12$-h exposure, $D$, lower panel) was used as loading control. Molecular mass markers and rRNA positions are indicated on the left.
5 a moderate decrease in cyclin D1 protein levels, respectively. In contrast, 27 clones did not exhibit reduced cyclin D1 protein levels. A representative Western blot analysis of two clones with markedly decreased cyclin D1 levels (C5 and C34) and one with moderately reduced cyclin D1 levels $(\mathrm{C} 7)$ is shown in comparison to PANC-1 and sham transfected cells (Fig. $1 A$ ). Equal levels of a 36-kD cyclin D1 band were seen in PANC-1 and sham transfected cells. In contrast, in the three selected clones there was a decrease in cyclin D1 protein levels of 35$81 \%$ in comparison with parental PANC-1 and sham transfected cells $(n=3, P<0.05)$. The same clones exhibited attenuated cyclin D1-associated kinase activities (Fig. $1 B$ ).

To examine whether the reduced cyclin D1 protein levels and reduced cyclin D1-associated kinase activities were due to the expression of cyclin D1 antisense, Northern blot analysis was performed next. Since the transcripts of the endogenous cyclin D1 and the exogenous cyclin D1 antisense are similar in size $(22,23)$, the blot was hybridized with specific cRNA probes that distinguished the sense and antisense cyclin D1 transcripts. When hybridized with the probe detecting exogenous cyclin D1 antisense (Fig. $1 C$ ), a 4.8-kb transcript was detected in all clones transfected with the cyclin D1 antisense construct. In contrast, no signal was obtained in PANC-1 or sham transfected cells. The level of cyclin D1 antisense expression in each clone correlated with the decrease in the cyclin D1 protein level (Fig. 1, $A$ and $C$ ). When hybridized with the probe detecting endogenous cyclin D1 sense mRNA (Fig. 1 $D$ ), a 4.4-kb transcript was present in PANC-1 and sham transfected cells and in cyclin D1 antisense transfected clones. Densitometric analysis with normalization to $7 \mathrm{~S}$ revealed that cyclin D1 mRNA levels were reduced by $39-70 \%$ in the anti-

A

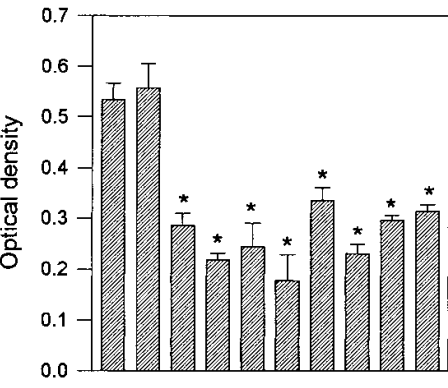

Figure 2. Characterization of the basal cell growth in cyclin D1 antisense expressing PANC-1 cells. (A) Anchorage-dependent growth. Indicated cells $(15,000 /$ well $)$ were seeded in 96-well plates and incubated for $48 \mathrm{~h}$ in complete medium before initiation of the
B

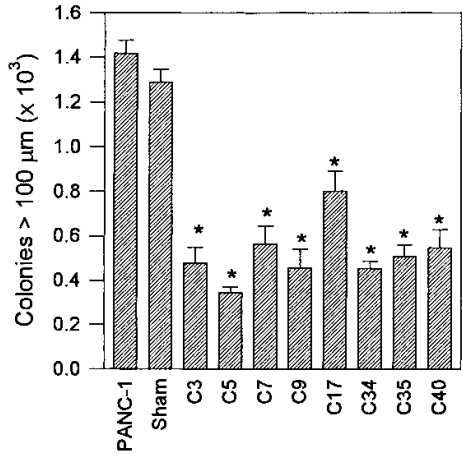

MTT assay. Results are shown as mean optical density values $( \pm$ SEM) of quadruplicate determinations from three separate experiments for each cell line. ${ }^{*} P<$ 0.015 compared with PANC-1 and sham transfected cells. $(B)$ Anchorage-independent growth. Indicated cells $(4,000 /$ well $)$ were seeded in 6-well plates in complete medium containing $0.3 \%$ agar. After $14 \mathrm{~d}$, colonies $>$ $100 \mu \mathrm{m}$ in diameter were counted by an inverted light microscope. Data are expressed as mean colony number $( \pm \mathrm{SD})$ of triplicate determinations for each cell line. ${ }^{*} P \leq 0.002$ compared with PANC-1 and sham transfected cells. 


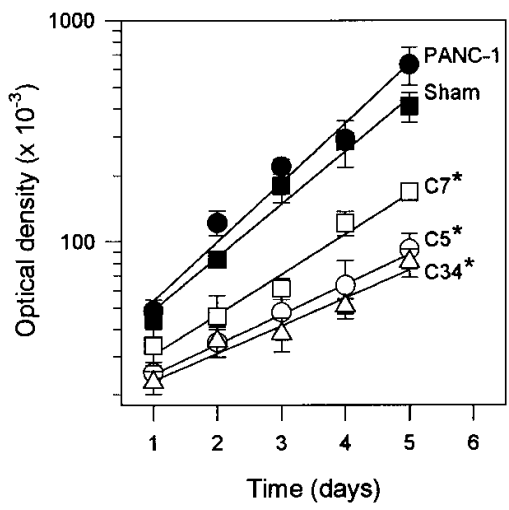

Figure 3. Determination of doubling times in PANC-1 cells. Indicated cells (3,000/well) were seeded in 96-well plates and incubated for the indicated time in complete medium. Results are shown as mean optical density values ( \pm SD) of quadruplicate determinations of each test point. $* P<$ 0.01 compared with PANC-1 and sham transfected cells.

sense expressing clones in comparison with PANC-1 and sham transfected cells.

Growth properties of cyclin D1 antisense expressing PANC-1 cells. Anchorage-dependent growth of parental PANC-1 cells, sham transfected cells, six cyclin D1 antisense expressing clones with markedly reduced cyclin D1 levels (C3, C5, C9, $\mathrm{C} 34, \mathrm{C} 35$, and $\mathrm{C} 40$ ), and two clones exhibiting moderately reduced cyclin D1 levels (C7 and C17) was compared using the MTT assay. The anchorage-dependent growth of all eight tested antisense expressing clones was reduced by $37-68 \%$ in comparison to PANC-1 and sham transfected cells (all $P$ values $<0.015$; Fig. $2 A$ ). Furthermore, PANC-1 and sham transfected cells displayed exponential doubling times of 26.4 and 28.8 h, respectively (Fig. 3). In contrast, the cyclin D1 antisense transfected clones C5, C7, and C34 displayed longer doubling times of 38.4-55.2 h. Doubling times were also determined by cell counting with similar results (data not shown). The cyclin D1 antisense expression also influenced the morphology of the cells. Thus, antisense transfected cells were larger, had more cytoplasm, and displayed a higher cytoplasmic to nuclear ratio compared with PANC-1 and sham transfected cells, while the size of the nucleus remained the same (Fig. 4).

The anchorage-independent growth of parental PANC-1 cells, sham transfected cells, and the above eight cyclin D1 antisense expressing clones was assessed by monitoring colony formation in soft agar (Fig. $2 \mathrm{~B}$ ). PANC-1 and sham transfected cells displayed colony forming efficiencies of 35 and $32 \%$, respectively. In contrast, the eight clones displayed 1.63.9-fold lower colony forming efficiencies ranging from 9 to $20 \%$ (all $P$ values $\leq 0.002$ ). Clones C7 and C17, which showed only moderate reduction of their cyclin D1 levels by Western blot analysis, displayed the highest colony forming efficiencies with 14 and $20 \%$, respectively, while the clones with marked reduction of their cyclin D1 levels displayed colony forming efficiencies of $9-12 \%$. In addition to the lower colony number, the colonies formed by the cyclin D1 antisense transfected cells were generally smaller (Fig. 5), probably reflecting the longer doubling times.

Next, the tumorigenicity of antisense cyclin D1 expressing cells was compared with sham transfected cells in athymic mice. To this end, $3 \times 10^{6}$ cells were subcutaneously injected at each site. All sites injected with sham transfected cells (4/4) developed visible multinodular tumors that measured $1.2-4.0 \mathrm{~cm}$ in largest diameter after $8 \mathrm{wk}$ (Fig. 6). In contrast, none of the sites that were injected with cyclin D1 antisense transfected cells $(0 / 12)$ developed tumors, even after $12 \mathrm{wk}(P=0.014)$.

Growth properties of cyclin D1 antisense expressing COLO357 cells. To confirm the specificity of the cyclin D1 antisense construct and to exclude the possibility of nonspecific effects due to clonal variation, we next established clones that express antisense cyclin D1 in a stable manner in COLO-357 cells. The anchorage-dependent growth of parental COLO-357 cells, COLO-357 cells transfected with the G418 resistance plasmid (sham-C), and two cyclin D1 antisense expressing clones (CC7 and (C9) that exhibited markedly reduced cyclin D1 levels (Fig. $7 A$ ) was compared using the MTT assay. The basal growth of clones CC7 and CC9 was inhibited by $45-56 \%$ in comparison with the growth of parental COLO-357 cells and sham-C transfected cells (all $P$ values $<0.0005$; Fig. $7 B$ ). Furthermore, clones $\mathrm{CC} 7$ and $\mathrm{CC} 9$ displayed doubling times of 57.6 and $52.8 \mathrm{~h}$, respectively, while parental COLO-357 and sham-C transfected cells displayed doubling times of 33.6 and $34.0 \mathrm{~h}$, respectively.

Effects of EGF, FGF-2, and IGF-I in cyclin D1 antisense expressing PANC-1 cells. EGF, FGF-2, and IGF-I (1 or $5 \mathrm{nM}$ ) alone or in triple combination significantly increased the

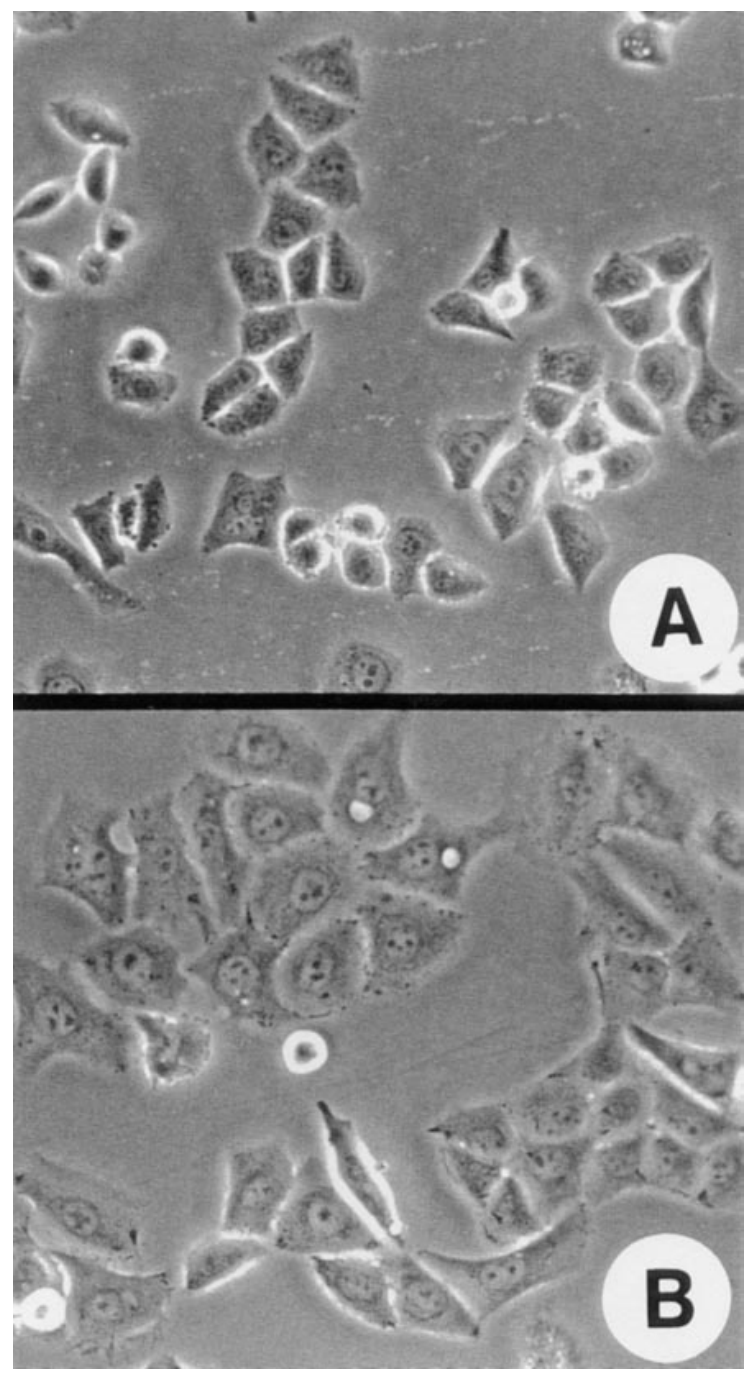

Figure 4. Cell morphology of PANC-1 cells. Exponentially growing sham transfected $(A)$ and cyclin D1 antisense transfected cells $(B)$ were photographed. Generally, antisense expressing cells were larger in size and displayed a higher cytoplasmic to nuclear ratio. $\times 900$. 

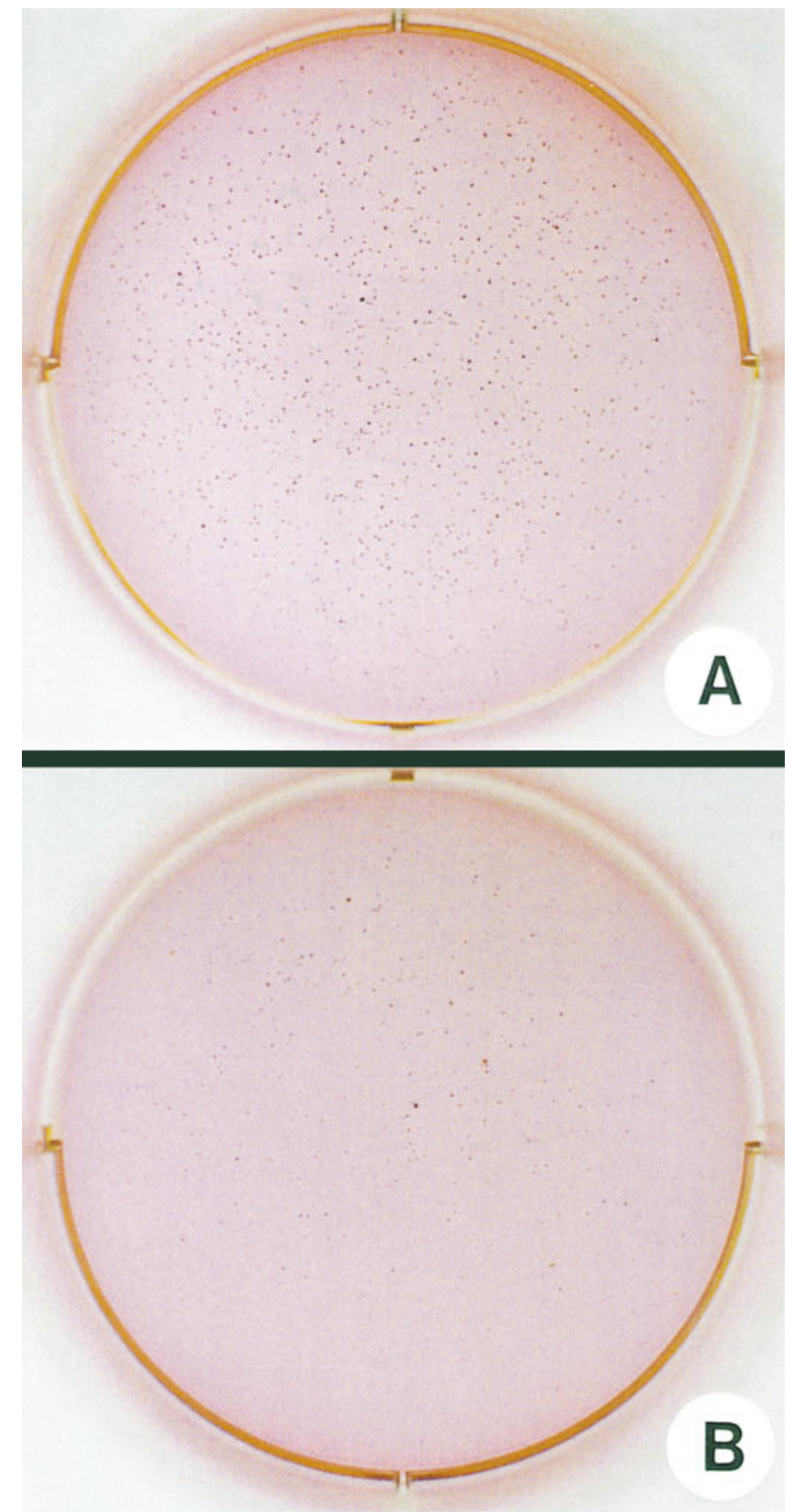

Figure 5. Soft agar assay for PANC-1 cells. Cells (4,000/well) were seeded in triplicate in 6-well plates in a $0.3 \%$ agar solution as described above. After $2 \mathrm{wk}$, the colonies were stained by adding $300 \mu \mathrm{g}$ MTT/well for $24 \mathrm{~h}$. Representative wells for sham transfected $(A)$ and cyclin D1 antisense transfected $(B)$ clones $(C 5)$ are shown. $\times 2.5$.

growth of PANC-1 and sham transfected cells. These increases ranged from 30 to $46 \%$ above growth of corresponding untreated controls (Table I). In contrast, the mitogenic effects of EGF, FGF-2, and IGF-I were completely blocked in cyclin D1 antisense expressing clones (Table I, all $P$ values $<0.04$ ). In Fig. 8, the growth stimulatory effects of $5 \mathrm{nM}$ EGF, FGF-2, and IGF-I are displayed for all tested cell lines.

To determine whether the abrogation of mitogenic response in antisense expressing clones was due to alterations upstream of cyclin D1, we next investigated the effects of EGF, FGF-2, and IGF-I on MAPK activity. ERK-1 and ERK-2

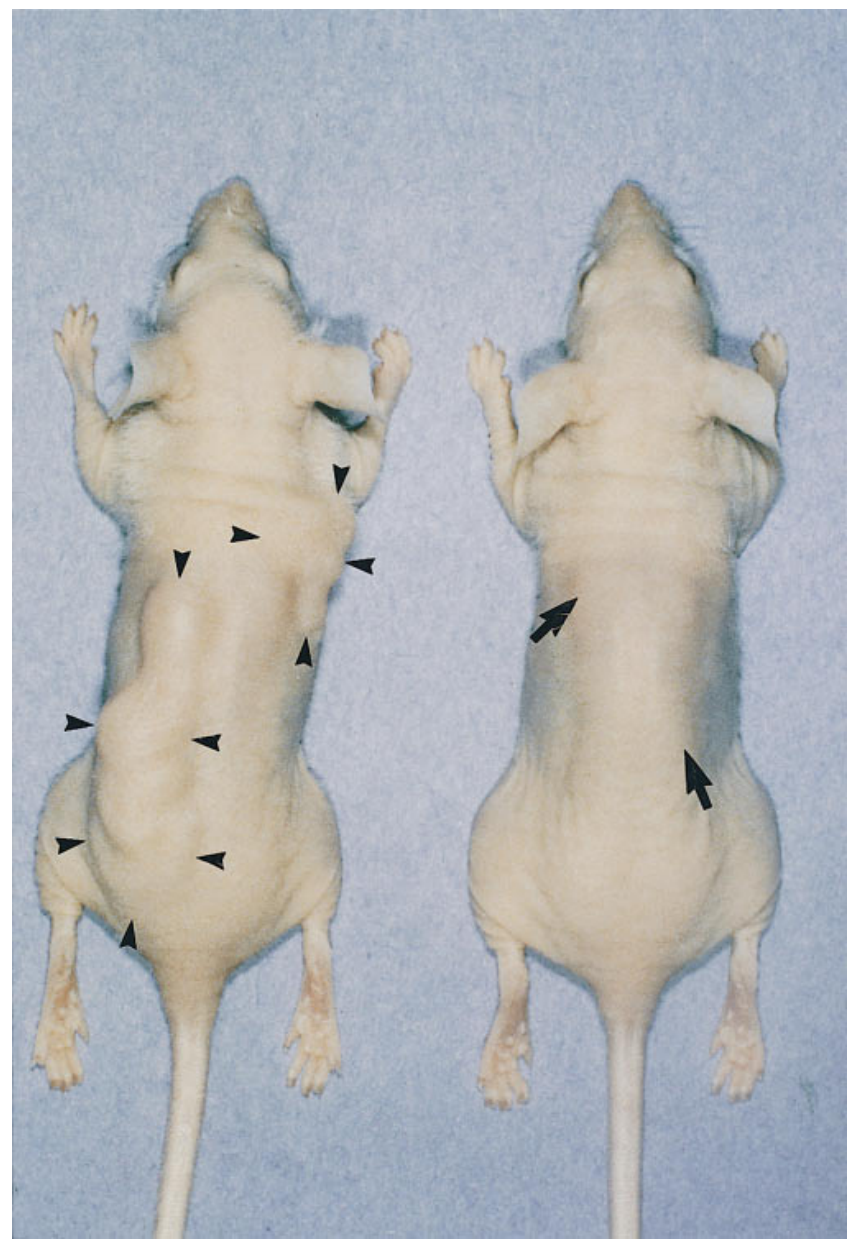

Figure 6. In vivo tumorigenicity of PANC- 1 cells. $3 \times 10^{6}$ cells were subcutaneously injected at each site in athymic nude mice. Sites injected with sham transfected cells (left mouse) developed multinodular tumors (outlined by arrowheads) within $8 \mathrm{wk}$. No tumors were visible at sites that were injected with cyclin D1 antisense transfected cells (arrows, right mouse), even after 12 wk.

were activated in a similar pattern in PANC-1 and sham transfected cells and in antisense transfected clones (Fig. 9), suggesting that cyclin D1 antisense expression did not inhibit signal transduction pathways upstream of the MAPK cascade.

Impact of cyclin D1 antisense expression on in vitro chemosensitivity. To determine whether cyclin D1 antisense expression altered the sensitivity of PANC-1 cells to chemotherapeutic agents, cells were incubated with various concentrations of cisplatinum. In a first set of experiments, cells were incubated for the maximal recommended time $(6 \mathrm{~h})$ for intraarterial infusion of cisplatinum (32; Fig. $10 A)$. At the maximal cisplatinum concentration shown $(25 \mu \mathrm{g} / \mathrm{ml})$, the growth of PANC-1 and sham transfected cells was inhibited by 15 and $17 \%$, respectively. In contrast, the same concentration of cisplatinum inhibited the growth of cyclin D1 antisense transfected clones by $34-41 \%$. The most significant differences (all $P$ values $<0.014)$ were observed at a concentration of $10 \mu \mathrm{g} / \mathrm{ml}$ cisplatinum, irrespective of whether growth was assayed by MTT (Fig. $10 A$ ) or by cell counting (data not shown).

Next, PANC-1 cells were incubated with the same cisplatinum concentrations, but for only $60 \mathrm{~min}$ (Fig. $10 \mathrm{~B}$ ). This time 

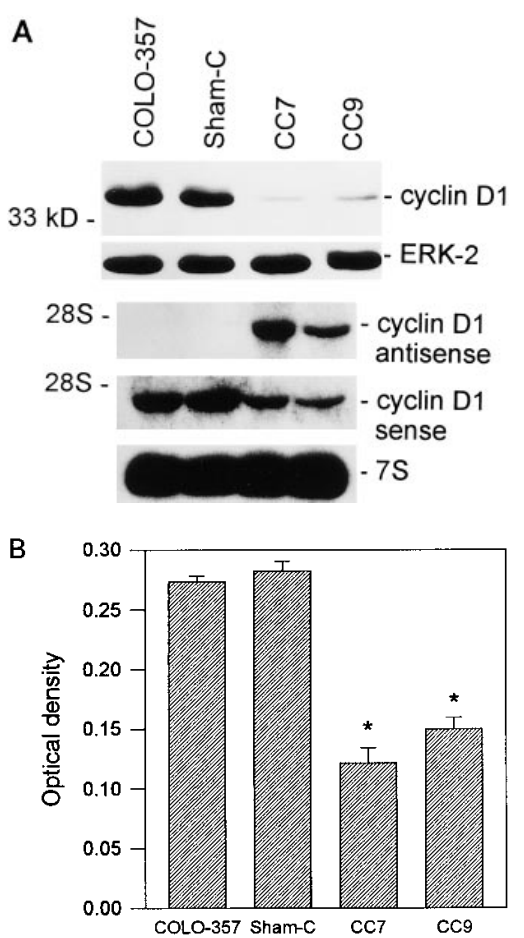

separate experiments for each cell line. $* P<0.0005$ compared with parental COLO-357 and sham-C transfected cells.

period is currently used for cisplatinum celiac artery infusion in pancreatic cancer patients in vivo (20). After $60 \mathrm{~min}$, cisplatinum exerted similar inhibitory effects in the cyclin D1 antisense expressing clones that had also been observed after the 6-h incubation period (Fig. 10, $A$ and $B$ ). In contrast, cisplatinum did not inhibit the growth of parental PANC-1 and sham transfected cells that were incubated for $60 \mathrm{~min}$ (Fig. $10 \mathrm{~B}$ ). The $\mathrm{LD}_{25}$ for cisplatinum in the antisense expressing clones ranged from 2 to $4 \mu \mathrm{g} / \mathrm{ml}$ and were $>25 \mu \mathrm{g} / \mathrm{ml}$ in PANC- 1 and sham transfected cells, respectively (Table II).

We next used the 60-min protocol to test the cisplatinum chemosensitivity of parental COLO-357, sham-C cells, and cyclin D1 antisense transfected clones CC7 and CC9. Cisplatinum $(25 \mu \mathrm{g} / \mathrm{ml})$ did not inhibit the growth of COLO-357 and sham-C cells (Fig. $10 \mathrm{C}$ ). In contrast, the same concentrations of cisplatinum inhibited the growth of CC7 and CC9 by 56 and

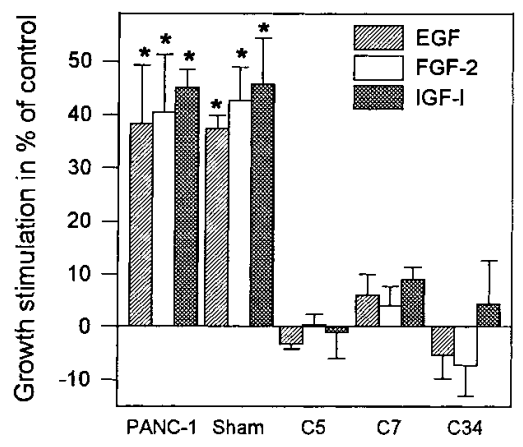

Figure 8. Effects of EGF, FGF-2, and IGF-I on the growth of PANC-1 cells. Indicated cells $(15,000 /$ well $)$ were seeded in 96-well plates, incubated for $24 \mathrm{~h}$ in complete medium, and then in serum-free medium for $48 \mathrm{~h}$ in the absence or presence of 5 $\mathrm{nM}$ of the indicated growth factors. Growth was determined by the

MTT assay. Results are expressed as percent growth stimulation compared with corresponding untreated controls and are shown as mean $( \pm$ SEM) of quadruplicate determinations of three separate experiments. $* P<0.05$ compared with corresponding untreated control.

$38 \%$, respectively (Fig. $10 \mathrm{C}$ ). The $\mathrm{LD}_{25}$ for cisplatinum were $<1 \mu \mathrm{g} / \mathrm{ml}$ in both antisense expressing COLO-357 clones and $>25 \mu \mathrm{g} / \mathrm{ml}$ in parental COLO-357 and sham-C cells.

\section{Discussion}

Cyclin D1 with its catalytic partners CDK4 and CDK2 is a critical modulator of cell cycle progression through $\mathrm{G}_{1}(1)$ and appears to have an important role in neoplastic transformation. Thus, the cyclin D1 gene is located on chromosome 11q13, in a region that contains several potential oncogenes and that is amplified in a number of malignancies, including carcinomas of the breast, esophagus, bladder, and lung, and squamous cell carcinomas of the head and neck $(14,34)$. This region is also the site of chromosomal translocations and rearrangements in $\mathrm{B}$ cell type neoplasms and parathyroid adenomas $(14,34)$. Elevated cyclin D1 mRNA levels have been reported in several of these malignancies (34) in association with shortened $G_{1}$, decreased cell size, and reduced dependency on mitogens (1113). Cyclin D1 inhibition by antibody microinjection or by transfection with a cyclin D1 antisense expression construct prevents normal fibroblasts from entering the $\mathrm{S}$ phase of the cell cycle and markedly inhibits the proliferation of human esophageal and colon cancer cells $(23,25,35)$ and murine lung cancer cells (36). Clinically, increased cyclin D1 levels have been correlated with decreased survival of patients with cancers of the pancreas $(21,22)$, esophagus (37), and breast (38).

Table I. Effect of Cyclin D1 Antisense on the Mitogenic Response of PANC-1 Cells to EGF, FGF-2, and IGF-I

\begin{tabular}{|c|c|c|c|c|c|c|c|c|}
\hline \multirow[b]{2}{*}{ Cell line } & \multicolumn{2}{|c|}{ EGF } & \multicolumn{2}{|c|}{ FGF-2 } & \multicolumn{2}{|c|}{ IGF-I } & \multicolumn{2}{|c|}{ EGF + FGF-2 + IGF-1 } \\
\hline & $1 \mathrm{nM}$ & $5 \mathrm{nM}$ & $1 \mathrm{nM}$ & $5 \mathrm{nM}$ & $1 \mathrm{nM}$ & $5 \mathrm{nM}$ & $1 \mathrm{nM}$ & $5 \mathrm{nM}$ \\
\hline PANC-1 & $31.0 \pm 3.1^{*}$ & $38.3 \pm 10.9^{*}$ & $32.7 \pm 6.2 *$ & $40.3 \pm 10.9 *$ & $34.7 \pm 3.5^{*}$ & $45.0 \pm 3.5^{*}$ & $47.5 \pm 6.5^{*}$ & $51.0 \pm 4.0 *$ \\
\hline Sham & $29.7 \pm 2.7 *$ & $37.3 \pm 2.4^{*}$ & $30.0 \pm 4.0 *$ & $42.7 \pm 6.2^{*}$ & $44.0 \pm 4.7 *$ & $45.7 \pm 8.7^{*}$ & $40.0 \pm 5.0 *$ & $42.7 \pm 5.2 *$ \\
\hline $\mathrm{C} 5$ & $2.7 \pm 6.9^{\ddagger}$ & $-3.3 \pm 0.9^{\ddagger}$ & $-1.7 \pm 5.5^{\ddagger}$ & $0.3 \pm 2.0^{\ddagger}$ & $-0.7 \pm 6.3^{\ddagger}$ & $-1.0 \pm 5.0^{\ddagger}$ & $2.0 \pm 3.5^{\ddagger}$ & $-2.3 \pm 4.1^{\ddagger}$ \\
\hline $\mathrm{C} 7$ & 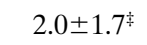 & $6.0 \pm 4.0^{\ddagger}$ & $9.7 \pm 0.3^{\ddagger}$ & $4.0 \pm 3.6^{\ddagger}$ & $-2.3 \pm 7.0^{\ddagger}$ & $9.0 \pm 2.3^{\ddagger}$ & $19.5 \pm 3.8^{\ddagger}$ & $18.4 \pm 5.7^{\ddagger}$ \\
\hline C34 & $-4.7 \pm 4.2^{\ddagger}$ & $-5.3 \pm 4.5^{\ddagger}$ & $-1.3 \pm 8.6^{\ddagger}$ & $-7.3 \pm 5.7^{\ddagger}$ & $7.3 \pm 2.6^{\ddagger}$ & $4.3 \pm 8.2^{\ddagger}$ & $11.0 \pm 6.8^{\ddagger}$ & $7.0 \pm 5.5^{\ddagger}$ \\
\hline
\end{tabular}

Results are expressed as growth stimulation in percentages above corresponding untreated controls. Data are shown as mean ( \pm SEM) of quadruplicate determinations from three separate experiments. *Significant growth stimulation compared with corresponding untreated controls $(P<0.05)$. ${ }^{\ddagger}$ Significantly reduced mitogenic response compared with sham transfected cells $(P<0.04)$. 
A
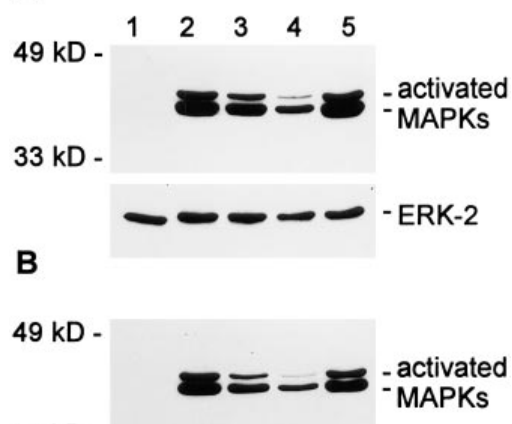

$33 \mathrm{kD}$ -

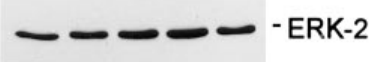

Figure 9. Effect of growth factors on the activation of ERK-1 and ERK-2 (MAPK) in PANC-1 cells. Sham transfected $(A)$ and cyclin D1 antisense transfected $(B)$ cells (C5) were stimulated for 10 min in the absence (lane 1) or presence of $5 \mathrm{nM}$ EGF (lane 2), FGF-2 (lane 3), IGF-I (lane 4), or the triple combination (lane 5). Cell lysates $(25 \mu \mathrm{g} / \mathrm{lane})$ were subjected to $12 \%$ SDSPAGE, electrotrans-

ferred to membranes, and blotted with a specific anti-active MAPK antibody (1:2,000,1-min exposure, upper panels). Membranes were reprobed with an anti-ERK-2 antibody (1:2,000, 1-min exposure, lower panels) to confirm equivalent loading. Molecular mass markers are shown on the left. Similar activation patterns were observed for parental PANC-1 cells and clones C7 and C34 (data not shown).

Furthermore, a significant proportion of human pancreatic cancers harbor a homozygous deletion or mutations of the p16 (MTS-1) tumor suppressor gene that encodes a specific cyclin D/CDK4 binding protein inhibiting CDK4 activity (39-41). Presumably, the $p 16$ mutations or deletions have the capacity to potentiate the oncogenic drive from overexpressed cyclin D1 in pancreatic cancer.

The aim of this study was to investigate the biological effects of a full-length cyclin D1 antisense cDNA construct that decreases cyclin D1 levels in pancreatic cancer cells. We preferred to use an antisense expression vector for the inhibition of cyclin D1 expression to the use of antisense oligodeoxynucleotides, because of the availability of a cyclin D1 antisense vector that has been used successfully in other carcinoma types $(23,25)$ and its potential practical advantages for in vivo cancer therapy (42). The same studies indicate that the integration of this vector into the genome does not result in nonspecific inhibitory effects $(23,25)$. In contrast to the several day half-life of oligodeoxynucleotides, the duration of action with intracellular expression vectors is up to several months $(42,43)$. Furthermore, suitable systems that specifically deliver the vector to the target cells with greater efficiency than antisense oligodeoxynucleotides may soon become available (42).

In this study we demonstrated that cyclin D1 antisense expression reduced cyclin D1 protein levels and cyclin D1-associated kinase activity and that these events were associated with significant inhibition of in vitro and in vivo cell proliferation in human pancreatic cancer cells. Furthermore, cyclin D1 antisense expression completely abrogated the mitogenic activity of EGF, FGF-2, and IGF-I. However, cyclin D1 antisense expressing cells still exhibited a marked increase in MAPK activation after addition of each of these growth factors. To our knowledge, this is the first demonstration that cyclin D1 antisense expression can block the mitogenic actions of ligands that activate transmembrane tyrosine kinase receptors. The fact that all three growth factors were still able to activate MAPK suggests that cyclin D1 may represent a final common pathway for mitogenic signaling via tyrosine kinase receptors
A

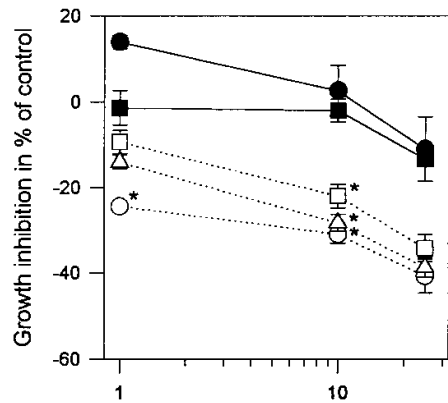

B

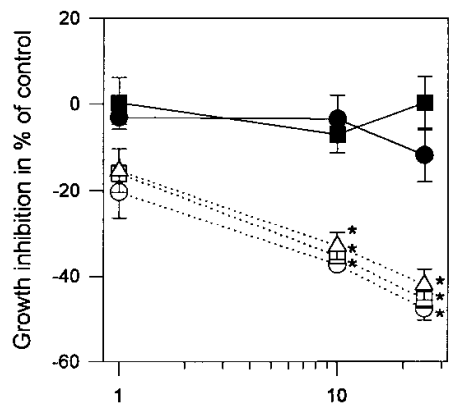

C

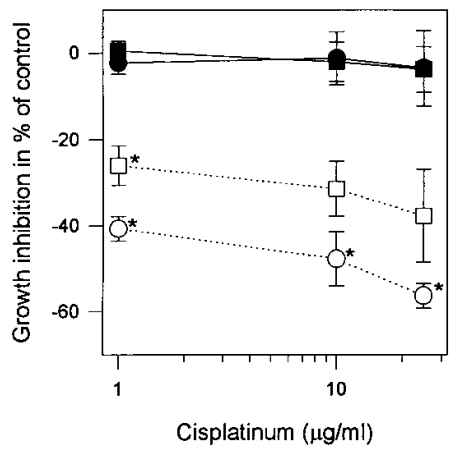

Figure 10. Effect of cisplatinum on cell growth. Indicated cells $(15,000 /$ well) were seeded in 96well plates and incubated for $48 \mathrm{~h}$ in complete medium. ( $A$ and $B$ ) Parental PANC-1 cells (filled circles), sham transfected cells (filled boxes), clone C5 (open circles), clone $\mathrm{C} 7$ (open boxes), and clone C9 (open triangles). (C) Parental COLO-357 cells (filled circles), sham-C cells (filled boxes), clone $\mathrm{CC} 7$ (open circles), and clone CC9 (open boxes). Cisplatinum was added for $6 \mathrm{~h}(A)$ or for $60 \mathrm{~min}(B$ and $C$ ) after $24 \mathrm{~h}$.

Growth was determined by the MTT assay. Results are expressed as percent growth stimulation compared with corresponding untreated controls and are shown as mean $( \pm$ SEM) of quadruplicate determinations of three separate experiments. $* P<$ 0.014 compared with parental cells and sham transfected cells.

in pancreatic cancer. This hypothesis is consistent with recent findings based on microinjection of cyclin D1 neutralizing antibodies that diverse mitogenic signals are strictly dependent on cyclin D1/CDK activity to induce cell cycle progression (26). In addition, our findings demonstrate that growth factorinduced mitogenesis can be abrogated in spite of MAPK activation.

PANC-1 cells express 400,000 EGF receptors per cell, produce TGF- $\alpha$ and amphiregulin (44-46), and harbor K-ras on-

Table II. Summary of the Growth Properties of Cyclin D1 Antisense Transfected Clones in Comparison with Sham Transfected PANC-1 Cells

\begin{tabular}{lcccc}
\hline & Sham & C5 & C7 & C34 \\
\hline $\begin{array}{l}\text { Cyclin D1 protein level (\% of sham) } \\
\text { Anchorage-dependent growth }\end{array}$ & 100 & 21 & 65 & 28 \\
$\quad(\%$ of sham) & 100 & 39 & 44 & 41 \\
$\begin{array}{l}\text { Doubling times (h) } \\
\text { Colony forming efficiency }\end{array}$ & 28.8 & 52.8 & 38.4 & 55.2 \\
$\quad(\%$ of seeded cells) & 32.2 & 8.6 & 14.1 & 11.4 \\
$\begin{array}{l}\text { Tumorigenicity in nude mice } \\
\mathrm{LD}_{25} \text { of cisplatinum }(\mu \mathrm{g} / \mathrm{ml}) \text { at } 60 \mathrm{~min}\end{array}$ & $4 / 4$ & $0 / 4$ & $0 / 4$ & $0 / 4$ \\
& $>50$ & 2 & 4 & 3
\end{tabular}


cogene and p53 tumor suppressor gene mutations and a homozygous deletion of the p16 tumor suppressor gene $(39,47$, 48). Human pancreatic cancers overexpress multiple growth factors and their tyrosine kinase receptors that activate the MAPK pathway (16-19). Additionally, they harbor K-ras and p53 mutations, as well as p16 mutations or deletions (39-41, 49) that may result in a decreased ability to turn off these excessively activated receptors and to slow down cell cycle progression. Therefore, the ability of cyclin D1 antisense to markedly suppress the growth of these cells suggests that cyclin D1 may be of paramount importance for pancreatic cancer cell growth. Although PANC-1 cells harbor a deletion of p16 (39, 48 ), the presence of this mutation is not essential for the growth inhibitory effect of the cyclin D1 antisense construct. Thus, the cyclin D1 antisense construct also reduced cyclin D1 levels in COLO-357 cells that have wild-type p16 (41), and attenuated the growth of the antisense transfected COLO-357 clones. Taken together, these observations raise the possibility that specifically blocking cyclin D1 activity may provide an efficient mechanism for simultaneously attenuating diverse mitogenic signaling pathways in pancreatic cancer.

One of the hallmarks of pancreatic cancer is the failure of standard chemotherapeutic agents to suppress tumor spread in vivo and cancer cell growth in vitro (20). Recently, it has been reported that cyclin D1 overexpression in a human fibrosarcoma cell line is associated with increased resistance to methotrexate (50), indicating that cyclin D1 overexpression can contribute to the resistance of cancer cells to chemotherapeutic agents. Indeed, in this study we found that the reduction of the cyclin D1 level was associated with a marked increase in chemosensitivity to cisplatinum in PANC-1 and COLO-357 cells. The in vivo achievable cisplatinum concentration that is not associated with significant clinical toxicity during an infusion time of $60 \mathrm{~min}$ in humans is at or below $10 \mu \mathrm{g} / \mathrm{ml}$ (32). When these conditions were recapitulated in vitro in the present study, cisplatinum significantly inhibited the growth of the antisense expressing clones, whereas no effects were observed in cells with normal cyclin D1 levels. Therefore, the therapeutic use of a cyclin D1 antisense strategy in parallel with the currently used celiac arterial axis cisplatinum chemotherapy protocol (20) could result in higher response rates to chemotherapy in vivo.

To our knowledge, this is the first report describing an increase in chemosensitivity that is associated with reduced cyclin D1 levels. The alkylating agent cisplatinum inhibits the growth of rapidly dividing cells in a cell cycle phase nonspecific manner by causing inter- and intrastrand DNA cross-links (51). It is not clear whether the increase in cisplatinum sensitivity of cyclin D1 antisense expressing cells is caused by a decrease in substrate or enzyme activities involved in DNA repair or by a decrease of P-glycoprotein activity resulting in intracellular accumulation of cisplatinum (51). Recently, we reported that abrogating mitogenic signaling through EGF receptor by transfecting PANC-1 cells with a truncated EGF receptor expression vector caused a modest increase in the growth suppressive actions of cisplatinum (52). In this study we blocked the mitogenic signaling of several growth factors by cyclin D1 antisense expression. Therefore, it is possible that the blockade of autocrine mitogenic signals might also be a mechanism for the increase in cisplatinum chemosensitivity.

Irrespective of the mechanisms, our observations suggest that cyclin D1 plays an important role in the pathobiology and aggressiveness of human pancreatic cancer and raise the possibility that future therapeutic strategies aimed at cyclin D1 may have the dual advantage of suppressing pancreatic cancer growth while enhancing the chemosensitivity of the tumor cells.

\section{Acknowledgments}

We thank K.H. Link (University of Ulm, Germany) for helpful discussions regarding the chemosensitivity assay, R.S. Metzgar (Duke University) for the generous gift of the human pancreatic cancer cell line COLO-357, G. Nascimoto (Chiron Co.) for the generous gift of human EGF, and J. Abrahams (Scios Nova Co.) for the generous gift of human FGF-2. The authors thank Dr. I. Bernard Weinstein from Columbia-Presbyterian Cancer Center, Columbia University, for providing the cyclin D1 antisense construct.

This study was supported by U.S. Public Health Service grant CA-40162 awarded by the National Cancer Institute to M. Korc. M. Kornmann was supported by grant Ko 1716/1-2 from Deutsche Forschungsgemeinschaft.

\section{References}

1. Pines, J. 1994. Protein kinases and cell cycle control. Semin. Cell Biol. 5: 399-408.

2. Grana, X., and E.P. Reddy. 1995. Cell cycle control in mammalian cells: role of cyclins, cyclin dependent kinases (CDKs), growth suppressor genes and cyclin-dependent kinase inhibitors (CKIs). Oncogene. 11:211-219.

3. Draetta, G.F. 1994. Mammalian G1 cyclins. Curr. Opin. Cell Biol. 6:842-846.

4. Sherr, C.J. 1994. G1 phase progression: cyclin on cue. Cell. 79:551-555.

5. Pardee, A.B. 1989. $\mathrm{G}_{1}$ events and regulation of cell proliferation. Science. 246:603-608.

6. Buchkovich, K., L.A. Duffy, and E. Harlow. 1989. The retinoblastoma protein is phosphorylated during special phases of the cell cycle. Cell. 58:10971105.

7. Dowdy, S.F., P.W. Hinds, K. Louie, S.I. Reed, A. Arnold, and R.A. Weinberg. 1993. Physical interaction of the retinoblastoma protein with human D cyclins. Cell. 73:499-511.

8. Even, M.E., H.K. Sluss, C.J. Sherr, H. Matsushime, J.-Y. Kato, and D.M. Livingston. 1993. Functional interactions of the retinoblastoma protein with mammalian D-type cyclins. Cell. 73:487-497.

9. Lam, E.W.-F., and N.B. La Thangue. 1994. DP and E2F proteins: coordinating transcription with cell cycle progression. Curr. Opin. Cell Biol. 6:859-866.

10. Wu, C.-L., L.R. Zukerberg, C. Ngwu, E. Harlow, and J.A. Lees. 1995. In vivo association of E2F and DP family proteins. Mol. Cell. Biol. 15:2536-2546.

11. Jiang, W., S.M. Kahn, P. Zhou, Y.-J. Zhang, A.M. Cacace, A.S. Infante, S. Doi, R.M. Santella, and I.B. Weinstein. 1993. Overexpression of cyclin D1 in rat fibroblasts causes abnormalities in growth control, cell cycle progression and gene expression. Oncogene. 8:3447-3457.

12. Quelle, D.E., R.A. Ashmun, S.A. Shurtleff, J.-Y. Kato, D. Bar-Sagi, M.F. Roussel, and C.J. Sherr. 1993. Overexpression of mouse D type cyclins accelerates G1 phase in rodent fibroblasts. Genes Dev. 7:1559-1571.

13. Resnitzky, D., M. Gossen, H. Bujard, and S.I. Reed. 1994. Acceleration of the G1/S phase transition by expression of cyclins D1 and $E$ with an inducible system. Mol. Cell. Biol. 14:1669-1679.

14. Motokura, T., and A. Arnold. 1993. Cyclins and oncogenesis. Biochim. Biophys. Acta. 1155:63-78.

15. Parker, S.L., T. Tong, S. Bolden, and P.A. Wingo. 1996. Cancer Statistics, 1996. CA Cancer J. Clin. 65:5-27.

16. Korc, M., B. Chandrasekar, Y. Yamanaka, H. Friess, M. Büchler, and H.G. Beger. 1992. Overexpression of the epidermal growth factor receptor in human pancreatic cancer is associated with concomitant increases in the levels of epidermal growth factor and transforming growth factor alpha. J. Clin. Invest. 90:1352-1360.

17. Kobrin, M.S., Y. Yamanaka, H. Friess, M.E. Lopez, and M. Korc. 1993. Aberrant expression of type I fibroblast growth factor receptor in human pancreatic adenocarcinomas. Cancer Res. 53:4741-4744.

18. Yamanaka, Y., H. Friess, M. Büchler, H.G. Beger, E. Uchida, M. Onda, M.S. Kobrin, and M. Korc. 1993. Overexpression of acidic and basic fibroblast growth factors in human pancreatic cancer correlates with advanced tumor stage. Cancer Res. 53:5289-5296.

19. Bergmann, U., H. Funatomi, M. Yokoyama, H.G. Beger, and M. Korc. 1995. Insulin-like growth factor I overexpression in human pancreatic cancer: evidence for autocrine and paracrine roles. Cancer Res. 55:2007-2011.

20. Link, K.H., F. Gansauge, J. Pillasch, and H.G. Beger. 1997. Multimodal therapies in ductal pancreatic cancer. The future. Int. J. Pancreatol. 21:71-83. 
21. Gansauge, S., F. Gansauge, M. Ramadani, H. Stobbe, B. Rau, N. Harada, and H.G. Beger. 1997. Overexpression of cyclin D1 in human pancreatic carcinoma is associated with poor prognosis. Cancer Res. 57:1634-1637.

22. Kornmann, M., T. Ishiwata, J. Itakura, P. Tangvoranuntakul, H.G. Beger, and M. Korc. 1998. Oncology. In press.

23. Zhou, P., W. Jiang, Y.-J. Zhang, S.M. Kahn, I. Schieren, R.M. Santella, and B. Weinstein. 1995. Antisense to cyclin D1 inhibits growth and reverses the transformed phenotype of human esophageal cancer cells. Oncogene. 11:571-580.

24. Moriai, T., M.S. Kobrin, C. Hope, L. Speck, and M. Korc. 1994. A variant epidermal growth factor receptor exhibits altered type a transforming growth factor binding and transmembrane signaling. Proc. Natl. Acad. Sci. USA. 91:10217-10221.

25. Arber, N., Y. Doki, E.K.-H. Han, A. Sgambato, P. Zhou, N.-H. Kim, T. Delohery, M.G. Klein, P.R. Holt, and I.B. Weinstein. 1997. Antisense to cyclin D1 inhibits the growth and tumorigenicity of human colon cancer cells. Cancer Res. 57:1569-1574.

26. Lukas, J., J. Bartkova, and J. Bartek. 1996. Convergence of mitogenic signaling cascades from diverse classes of receptors at the cyclin D-cyclindependent kinase-pRb-controlled G1 checkpoint. Mol. Cell. Biol. 16:6917-6925.

27. Matsushime, H., D.E. Quelle, S.A. Shurtleff, M. Shibuya, C.J. Sherr, and J.-Y. Kato. 1994. D-type cyclin-dependent kinase activity in mammalian cells. Mol. Cell. Biol. 14:2066-2076.

28. Mossmann, T. 1983. Rapid colorimetric assay for cellular growth and survival: application to proliferation and cytotoxicity assays. J. Immunol. Methods. 65:55-63.

29. Kornmann, M., T. Ishiwata, H.G. Beger, and M. Korc. 1997. Fibroblast growth factor-5 stimulates mitogenic signaling and is overexpressed in human pancreatic cancer: evidence for autocrine and paracrine events. Oncogene. 15: $1417-1424$.

30. Raitano, A.B., and M. Korc. 1990. Tumor necrosis factor up-regulates $\gamma$-interferon binding in a human carcinoma cell line. J. Biol. Chem. 265:1046610472 .

31. Baldwin, R.L., and M. Korc. 1993. Growth inhibition of human pancreatic carcinoma cells by transforming growth factor beta-1. Growth Factors. 8: 23-34.

32. Link, K.H., G. Leder, J. Pillasch, U. Butzer, L. Staib, M. Kornmann, U.B. Brückner, and H.G. Beger. 1998. In vitro concentration response studies and in vitro phase II tests as the experimental base of regional chemotherapeutic protocols. Semin. Surg. Oncol. In press.

33. Hamburger, A.W., and S.E. Salmon. 1977. Primary bioassay of human tumor stem cells. Science. 197:461-463.

34. Hall, M., and G. Peters. 1996. Genetic alterations of cyclins, cyclin-dependent kinases, and Cdk inhibitors in human cancer. Adv. Cancer Res. 68:67-108.

35. Baldin, V., J. Lukas, M.J. Marcote, M. Pagano, and G. Draetta. 1993. Cyclin D1 is a nuclear protein required for cell cycle progression in G1. Genes Dev. 7:812-821.

36. Schrump, D.S., A. Chen, and U. Consoli. 1996. Inhibition of lung cancer proliferation by antisense cyclin D. Cancer Gene Ther. 3:131-135.

37. Naitoh, H., J. Shibata, A. Kawaguchi, M. Kodama, and T. Hattori. 1995. Overexpression and localization of cyclin D1 mRNA and antigen in esophageal cancer. Am. J. Pathol. 146:1161-1169.

38. McIntosh, G.G., J.J. Anderson, I. Milton, M. Steward, A.H. Parr, M.D. Thomas, J.A. Henry, B. Angus, T.W.J. Lennard, and C.H.W. Horne. 1995. De- termination of the prognostic value of cyclin D1 overexpression in breast cancer. Oncogene. 11:885-891.

39. Caldas, C., S.A. Hahn, L.T. da Costa, M.S. Redston, M. Schutte, A.B. Seymour, C.L. Weinstein, R.H. Hruban, C.J. Yeo, and S.E. Kern. 1994. Frequent somatic mutations and homozygous deletions of the p16 (MTS1) gene in pancreatic adenocarcinoma. Nat. Genet. 8:27-32.

40. Huang, L., T.L. Goodrow, S.-Y. Zhang, A.J.P. Klein-Szanto, H. Chang, and B.A. Ruggeri. 1996. Deletion and mutation analyses of the p16/mts-1 tumor suppressor gene in human ductal pancreatic cancer reveals a higher frequency of abnormalities in tumor-derived cell lines than in primary ductal adenocarcinomas. Cancer Res. 56:1137-1141.

41. Naumann, M., N. Savitskaia, C. Eilert, A. Schramm, H. Kalthoff, and W. Schmiegel. 1996. Frequent codeletion of p16/MTS1 and p15/MTS2 and genetic alterations in p16/MTS1 in pancreatic tumors. Gastroenterology. 110: $1215-1224$.

42. Weiss, B., G. Davidkova, and S.-P. Zhang. 1997. Antisense strategies in neurobiology. Neurochem. Int. 31:321-348.

43. Kawasaki, H., M. Machida, M. Komatsu, H.-O. Li, T. Murata, H. Tsutsui, A. Fujita, M. Matsumura, Y. Kobayashi, K. Taira, and K.K. Yokoyama. 1996. Specific regulation of gene expression by antisense nucleic acids: a summary of methodologies and associated problems. Artificial Organs. 20:836-848.

44. Korc, M., P. Meltzer, and J. Trent. 1986. Enhanced expression of epidermal growth factor receptor correlates with alterations of chromosome 7 in human pancreatic cancer. Proc. Natl. Acad. Sci. USA. 83:5141-5144.

45. Smith, J.J., R. Derynck, and M. Korc. 1987. Production of transforming growth factor alpha in human pancreatic cancer cells: evidence for a superagonist autocrine cycle. Proc. Natl. Acad. Sci. USA. 84:7567-7570.

46. Yokoyama, M., H. Funatomi, C. Hope, D. Damm, H. Friess, M.W. Büchler, J. Abraham, and M. Korc. 1996. Heparin-binding EGF-like growth factor expression and biological action in human pancreatic cancer cells. Int. J. Oncol. 8:289-295.

47. Berrrozpe, G., J. Schaeffer, M.A. Peinado, F.X. Real, and M. Perucho. 1994. Comparative analysis of mutations in the p53 and K-ras genes in pancreatic cancer. Int. J. Cancer. 58:185-191.

48. Liu, Q., Y.-X. Yan, M. McClure, H. Nakagawa, F. Fujimura, and A.K. Rustgi. 1994. MTS-1 (CDKN2) tumor suppressor gene deletions are a frequent event in esophagus squamous cancer and pancreatic adenocarcinoma cell lines. Oncogene. 12:619-622.

49. Rozenblum, E., M. Schutte, M. Goggins, S.A. Hahn, S. Panzer, M. Zahurak, S.N. Goodman, T.A. Sohn, R.H. Hruban, C.J. Yeo, and S.E. Kern. 1997. Tumor-suppressive pathways in pancreatic carcinoma. Cancer Res. 57: 1731-1734.

50. Hochhauser, D., B. Schnieders, E. Ercikan-Abali, R. Gorlick, R. MuiseHelmericks, W.-W. Li, J. Fan, D. Banerjee, and J.R. Bertino. 1996. Effect of cyclin D1 overexpression on drug sensitivity in a human fibrosarcoma cell line. $J$. Natl. Cancer Inst. 88:1269-1275.

51. Black, D.J, and R.B. Livingston. 1990. Antineoplastic drugs in 1990. A review (Part II). Drugs. 39:652-673.

52. Wagner, M., T. Cao, M.E. Lopez, C. Hope, K. Van Nordstrand, M.S Kobrin, H.U. Fan, M.W. Büchler, and M. Korc. 1996. Expression of a truncated EGF receptor is associated with inhibition of pancreatic cancer cell growth and enhanced sensitivity to cisplatinum. Int. J. Cancer. 68:782-787. 